\title{
SURVIVING TO TELL THE TALE: NO ONE IS HERE EXCEPT ALL OF US
}

\author{
Cristina CHEVEREȘAN ${ }^{*}$ \\ West University of Timişoara, Romania
}

\begin{abstract}
The article focuses on Romanian-American Ramona Ausubel's 2012 No One Is Here Except All of Us. Written in English by a second-generation immigrant to the United States, the World War II story unfolds dramatically as a fable that relies upon community, memory and imagination. It revolves around the protagonists' shared belief that by erasing and reinventing their past, by starting their lives anew via reshuffled creation myths, their small assembly of forgotten individuals might survive in an enclave of its own, fantastic. This makes Ausubel's unique approach to the Holocaust and its pogroms part of a compelling series of trauma narratives, as a biographically-informed fictional account of factual circumstances. By emphasizing the crucial, cathartic dimension of storytelling and employing it textually and meta-textually, the book blurs the boundaries between genres. The author's mediated insight into community stereotyping, persecution, solidarity and, ultimately, migration, and its skillful integration into a postmodern (counter) fairytale, will be scrutinized as valuable and effective contemporary awareness-raising tools.
\end{abstract}

Keywords: fantasy; Holocaust; memory; representation; Romania; storytelling; survival; trauma.

\section{INTRODUCTION. THE SALUTARY POWER OF IMAGINATION}

As a Romanian scholar in the field of American Studies, with a long-standing interest in ethnic American literature(s), I have long been fascinated by the creative ways in which various generations of immigrant U.S. writers decide to capture and fictionalize their relationship to their native countries. Ramona Ausubel's acclaimed debut novel, No One Is Here Except All of Us (2012), is a gripping account based on her own predecessors' experience of the Holocaust, and on the ensuing orally-transmitted tales. More precisely, the protagonist, Lena, is modeled upon the author's grandmother, born in 1920 in a portion of 
the Carpathian Mountains that then belonged to Romania. Although the novel can hardly be read as an (auto)-biography, it relies heavily on real-life events, as filtered through the memory, sensitivity, and emotional reactions of a first-hand witness, and subsequently reinterpreted and fictionalized by a contemporary, remote, yet not detached, heiress of the painful legacy.

The preamble to the novel makes the circumstances clear: "It began in 1939, at the northern edge of Romania" (Ausubel 3). What was once a quiet, tranquil, ancestral Jewish settlement inhabited by nine families, in a valley upon the Dniester, is gradually but irreversibly torn apart by the irrepressible forces of history, as the reader learns in retrospect: "We are a forty-day walk from Iasi, and two weeks to Lvov. We are safe here,' the baker said. 'Chernowitz is only forty-seven kilometers', the healer said" (Ausubel 11). It is the beginning of a negotiation of reality, wherein the inhabitants of the village decide to elude their potentially-and eventually, inevitably-tragic fate by resorting to the conjoint powers of faith and language. A brief letter to an innocent child born in the USA after the war, whose future will remain forever marked by the forefathers' past, addresses the past obliquely, though unequivocally:

Our lives belonged to this place-we did not want to move them elsewhere, even though we knew that, in another country not so far away, a man with a square mustache wanted to remake the world. People like us were forced to register all wealth and property. Passports were stamped with a large red J. A curfew was set. It was a new chapter of an old story. Somewhere, a temple exploded in flames. Czechoslovakia was seized, Warsaw. People like us were gathered in ghettos. All men were Israel and all women Sarah. (Ausubel 4)

Opening the book, at once anticipating and rehearsing the crude generalizations, unforgiving stereotypes, and harsh realities of the World War from an Eastern and Central-European perspective, the survivor mother's message to her newborn (American) daughter, symbolically named Chaya (Life), frames the major purpose of this type of narrative: remembrance via communication. "Someday your children will ask what happened, and you will tell a new version, and this way, the story will keep living. The truth is in the telling” (Ausubel 3). No One is Here Except All of Us strives to become a part of the grand narrative of the Holocaust by capturing fragments of Ausubel's family (hi)story and weaving them into a story that can speak effectively to a third millennium audience. It revives experiences and feelings to which direct access has long been lost. Ausubel's magic realism, the lyricism and depth of her fablelike narrative, not only make for a beautifully crafted novel, but also bring forth a delicate, yet thought-provoking method of blending micro- and macrohistories, individual and communal memories, via the salutary power of imagination. 


\section{A PARENTHESIS BETWEEN CATASTROPHES}

Michael Rothberg's Traumatic Realism: The Demands of Holocaust Representation makes a convincing plea for the importance of investigating such works as insightful, original, and provocative prompts for rethinking one of humanity's most atrocious man-made catastrophes and its implications.

The analysis of literary, philosophical, and artistic responses to the Holocaust sheds new light on many familiar debates on the recent 'theory wars' [...] Furthermore, close study of this particular catastrophe helps us reflect on the insistent presence of related phenomena in our own culture: exploring the recent fascination with the Holocaust means exploring a more general contemporary fascination with trauma, catastrophe, the fragility of memory, and the persistence of ethnic identity. (2-3)

Along these lines, my aim is to look at the original means in which Ausubel, who grew up in Santa Fe, translates national, ethnic, religious group struggles into literature, as well as at her remarkable skill in producing an alternative, yet compelling image of the perhaps lesser-studied phenomenon of the Holocaust in the disputed territories of Northern Romania.

Resorting to both close reading and a cultural studies-based approach to the novel's context and narrative choices, one feels compelled to analyze this utopian epic of coping with trauma, focusing on the interaction of myth-making and experiment, symbolism and remembrance. An important part of the novel takes place in a secluded, almost idyllic village whose Jewish inhabitants chose to survive the horrors of grim circumstances by reinventing themselves, rewriting their history and practically seeking shelter in an imaginary homeland. Warned by a pogrom survivor (the "stranger" whom they literally pull from the muck) about the tragedy of a war that has ravaged the world and is steadily approaching, they hear about the concrete side of what, until then, seemed a rather abstract threat they had accidentally read about in a newspaper. "'The soldiers were allowed to do whatever they wanted to us for twenty-four hours,' she said. 'A reward to them, a punishment for us. They cut off my mother's breasts and my sister's ears. They lit my husband's beard on fire'” (Ausubel 19).

This glimpse into the grotesque cruelty of the pending apocalypse triggers a confounding reaction of solidarity in the face of despair and destruction. The villagers turn to the teachings of Jewish history, which Ausubel summarizes in a number of powerful pages. Their message brings forth the power of storytelling as ultimate community salvation. "All the while, we told the stories back and they kept us alive as a people [...]. We began again and again, across the face of the earth" (Ausubel 22). Thus, the choice becomes evident: they will withstand the tides of time by relocating and disconnecting themselves from reality, cutting all ties to society at large, and creating an 
enclave of their own, a fragile bubble of oxygen in a menacingly toxic universe. As Jenny Hendrix notes for the LA Review of Books, "art, in the novel, provides a barrier to an increasingly savage real, the indifference to fact crumbling the reality the village seeks to avoid. Style is literalized, and the impossible facts of history are both processed and avoided by a turn to fantasy" (Hendrix).

It is, therefore, particularly interesting to place Ausubel's unique approach to the Holocaust within the growing body of trauma narratives dealing with modern and contemporary socio-historical events, as well as to investigate the influence of the author's Eastern European background upon her fictional account of factual circumstances. Her biographically-informed insight into community stereotyping, persecution, solidarity and, eventually, migration, and its skillful integration into a postmodern (counter) fairytale are to be scrutinized as valuable and effective contemporary awareness-raising tools. The villagers' forefathers' ominous self-imposed journey into self-annihilation as survival strategy against the previous world war is resonant of an entire tradition of forced reinventions.

The little group, our heavy-headed and tired grandparents, the few to survive the latest pogrom, walked with their pairs of goats, sheep, dogs and horses for forty-one days from the town of Iasi through Bukovina. The grandparents brought languages and coins from all the places everyone had lived - Spanish pesetas, Italian lire, Austro-Hungarian kronen, Polish zlotys, pieces of Ottoman silver, Yugoslavian copper, ancient Syrian gold and new Russian paper. They had German curse words, Polish love songs, English poems, Hebrew prayers and Yiddish scoldings. They had wandered and traded, wandered and traded, and they had been filled up with words [...] For twenty years, they lived like forgotten people. They were a long way from other villages, and farther still from any cities. The only way they knew they were alive was by repeating the stories again and again: the first man and the first woman, the great flood, the plague of frogs, the plague of darkness. All the stories were stories of wandering, of being lost, of starting again. (Ausubel 26-7)

This creation myth of the isolated Zalischik community, its echoes of the structure and adventures of Noah's Ark, prefigure the reshuffled Genesis that articulates the New World that the Second World War villagers decide to (re)invent for themselves. No One Is Here Except All of Us imagines the parallel universe they take refuge in upon the startling realization that they find themselves (literally and figuratively) at the heart of a continent which is politically, militarily and socially intent on annihilating them as if they were its lethal plague. At a historical moment apparently lacking practical and reasonable solutions, they resort to the unique power of belief: they go back to the Book of Genesis and rewrite it in their own code, as their own primeval history. "We need a story $[\ldots]$ When there is nothing left to do, and there is nowhere else to 
go, the world begins again” (Ausubel 32). By emphasizing the crucial, cathartic dimension of storytelling, and employing it textually and meta-textually, Ramona Ausubel's book blurs the boundaries between genres. It relies upon typically postmodern historiographic metafiction (creatively recuperating, reinterpreting, and recreating factual data), while toying with the popular utopian fantasy genre and employing a quasi-fairytale-like tone for highly specific purposes.

\section{SURVIVE TO TELL THE TALE}

As a consequence, unsurprisingly, the manuscript's labeling by various websites and reader reviews ranges from magical realism to war novel, Holocaust memoir, adult fiction, Jewish writing, or Romanian-American (immigrant) literature. Thus, it proves worthy of examination in terms of its complexity and innovative nature, as well as the effects of the employed narrative strategies upon the multiple categories of readers it manages to address. The study of a poetical, yet powerful fable, which equally echoes Foer, Marquez, Singer, or even Benigni (in another, yet not altogether different, storytelling medium), may capture the advent of a new (st)age in trauma writing, which makes the past tangible and comprehensible to Third Millennium audiences in search of engaging, non-conventional pathways to knowledge. Lena, the story's protagonist, undergoes several traumatic transformations, which accustom her to identity renunciation and renewal. Hers, like her community's, is a story of simultaneous loss and salvation, a vicious circle of death and survival, a constant vacillation between one or another state of captivity and attempts to escape into freedom.

Moreover, hers, like her community's, is a story that must be told. The healing, regenerative power of storytelling is the red thread that gives cohesion to the narrative of Ausubel (and her characters), as suspected by the village's greengrocer: "If we die, every single one of us? The story, he thought, remained. Once told, it does not ever go completely away" (Ausubel 286). It is, therefore, not surprising that when Lena must eventually face a reality that has been kept from her for an entire lifetime, she is invested with the power and responsibility to preserve and pass on the legacy of her extended family. Her survival is no longer an individual matter, but rather a communal one, upon which inscription in or erasure from history rests: “'You have to survive to tell what happens,' the stranger said. 'That's your job now”' (Ausubel 228). In many ways, Ausubel proves just as committed to her job as her protagonist, striving for closure in the name of the forgotten, departed or merely voiceless, struggling with her grandmother's recollections of things past and the impossibility of an accurate present articulation. 
In their introduction to Witnessing the Disaster: Essays on Representation and the Holocaust, Michael-Bernard Donals and Richard Glezjer point to the difficulty of such a narrative undertaking:

We do not remember a traumatic event so much as we "take leave of it," in Caruth's terms, though it leaves an indelible mark on everything we say, including the subject of the narrative of the event. It is at the point of "losing what we have to say" that we speak, and the writing begins. The distance between what has been witnessed and what can be committed to testimony what was seen and what can be said - is often wide and always palpable: not only in the witness's statements but in the shrugged shoulders, the winces, the tears, and the silences that punctuate written and oral testimonies. (7)

In the Note from the Author that accompanies her book, Ausubel confesses her initial discouragement from the endeavor that she hoped to undertake when she recorded her grandmother's stories and went through the physical and mental souvenirs her family had kept and her characters undergo similar difficulties. It is not a coincidence that, after having renounced their identities and forged safer, more suitable ones, choosing to be forgotten and lost to the rest of the world, many of the villagers become patients, "people whose anxiety about the old, the new, the broken and the saved was manifested in strange physical afflictions" (Ausubel 96). Although not ghettoized and terminated like the fellow Jews whose stories they had consciously blocked out and whose fates some managed, thus, to avoid, the people are torn apart by the trauma of depersonalization, of being forced to reconfigure their lives, expectations, families, beliefs in order to stay alive. The novel digs deep into the psychological challenges of trauma, whether voiced or muted, openly stated or carefully, instinctively, and obstinately buried.

The small universe of Zalischik has been literally turned upside down by the proximity of war and catastrophe. While the villagers play make-believe that they are alone and free to build a world of their own, the reality they pretend does not exist unfolds and envelops them. Like a reversed looking-glass, it is, in fact, the outside world that ignores their existence until the dramatic moment of collision. When echoes of events and people beyond the artificial boundaries of the closed-in community eventually reach it, the futility of a utopian mental and social construct strikes as hard as it can, and the inherent moral dilemmas of crisis creep in and take over. The isolation from the horrors of the war is, undoubtedly, a temporary solution, but it also involves self-denial and painful renunciation of deep connections and unbreakable bonds.

He thought about his brother, the potential children with their running noses and flattened hair. The door our village had built, opened and walked through only existed for us - to the rest of the world the only likely explanation was that we 
were dead. Not re-created, not wrapped in wisps of clouds summoned in the sky just for us, but shot, drowned, worm-eaten, dismembered. Extinguished, just as we thought they had been. (Ausubel 112)

\section{THE BURDEN OF MEMORY}

This perversity of the game of smoke and mirrors the Holocaust forces the Jewish community into playing is captured in various symbolic episodes throughout the book, to which dehumanization, depersonalization, dismembering and quasi-disappearance as an individual become central. As a young girl, Lena is torn from her family by the invented New World Order, which requires her to leave home and grow into a different person, the prodigious daughter of her childless aunt and uncle. Her predicament, then, reflects the larger condition of a collective, the physical and spiritual boundaries of which never cease to fluctuate and alter its sense of wholeness, safety, belonging. Feeling "cut in half" for the first time, she is taught a lesson she will not be given the chance to unlearn: "Your body has to live here, but your heart can live wherever you like" (Ausubel 94).

The splitting of the self, the division of affection, the constant interplay between betrayal and forgiveness dominate the dark territories of uncertainty, even when disguised as serene and harmonious. Like her true mother, Lena will find herself in a position to give up on her son, Solomon, as she believes it to be the only way to keep him alive while they are running away from the horrors of the war although, later on, she finds out that they were, in fact, safe after having escaped behind Soviet lines, which she could not have known in the absence of maps and information. The parallelism between her and her son's situations, the maternal (self)-sacrifice, the dilemmas and, once more, the traumas of separation and transformation nevertheless remain. They stand as haunting proof of the type of war horrors that rarely get recorded in the factual histories of events. It becomes evident, as Cathy Caruth (4) explains in her reading of Freud's writings on trauma, that

trauma seems to be so much more than a pathology, or the simple illness of a wounded psyche: it is always the story of a wound that cries out, that addresses us in the attempt to tell us of a reality or truth that is not otherwise available. This truth, in its delayed appearance and its belated address, cannot be linked only to what is known, but also to what remains unknown in our very actions and our language.

In the book, numbed down feelings frequently burst belatedly when guilt, regret, and unutterable sadness surface unexpectedly, when the apparent order of things is disrupted by reconnections with a repressed, denied, rejected 
or altogether erased past. Ausubel oftentimes uses essential existential moments to illustrate the relativization that accompanies a lifetime of struggles to overcome ongoing crises of "normality". Birth, growth, marriage, habitually celebrated, are nothing but further wounds for Lena, whose life, a miniature replica of the community's, has been a series of disappointments, failures, and departures from her childhood dreams and peacetime expectations. For instance, her self-analytical flashbacks of her arranged marriage and her experience as a child-bride expose the kind of out-of-the-body experience that trauma entails, the (sometimes indefinitely) postponed reaction, the paralysis of the senses and anaesthetization of the mind.

And me? What did I feel? Thinking of that day, it is as if I were not there. As if someone had told me what happened later. I must have made each required movement, passing through the wheels that turned me from a girl to a wife. If there was a transformation, I did not witness it. Still, I was no more afraid of one made-up version of my life than another. I was already far away from anything that had ever been true, and somewhere in this was a surprising sense of peace. I had nothing left to lose. (Ausubel 168)

Both praised and criticized, Ausubel's technique is that of reflecting the grand trauma of the Holocaust indirectly, via its effects upon a community it destroys in subtle and irreparable ways, although it does not subject it to the incarceration-and-termination experience that has come to be perceived as typical of the Jewish narrative of the Second World War. On the contrary, it seems to fall into the category of writings in which the violent cessation of physical being and the inevitable confrontation with death (one's own and the relatives', acquaintances' etc.) is not necessarily central but rather the torment of having avoided it, the ongoing burden of survival and remembrance. Moreover, particularly in the first half, it seems to incorporate the specific manner of employing the midrash that is mentioned, for example, in Lucy Dawidowicz' Introduction to A Holocaust Reader.

Speaking about the system of allusions, references, and signals that Jewish communities were forced by various episodes in a troubled history to develop as means of communication beyond the authorities' understanding, she points out the rabbis' employment of Aesopian techniques:

to comfort and console by invoking the stories and legends of the past as a commentary on the present $[\ldots]$ The fable, the midrash, the parable became modes of public discourse for the Jews in Germany after 1933 when they lived in precarious instability between freedom and the ghetto, still allowed to congregate and publish, but subject to ever tighter restrictions and severer penalties for transgressing them. (Dawidowicz 17-8) 
The novel's initial overlapping of realities, the reconstruction of the world in seven days after a reading from The Book of Genesis has been disrupted by a threatening warplane, seems to render a similar situation, in which the public sermon, the religiously-infused discourse, the expansive quotation and (re)interpretation of the sacred texts function as pillars of strength for a community in dire need of moral guidance. Ausubel's fantastic universe is precisely one of merely apparent stability, in which freedom hangs by an illusory thread and the villagers embrace a radical vision of Edenic existence, which is far removed from reality, in more ways than one. By inventing its own new language, objects, relationships etc., the community naively hopes to deter the flood of historical events that will, eventually, drown it. Lena's story goes on as she escapes, eventually, to America, and thus the collective story itself is kept alive and told anew by the generations to follow.

The protagonist's spokesperson quality is all the more important as she becomes representative of an entire communal spirit. While villagers are washed away by war and water, they lose individual characteristics, they melt into a mass wherein "survival was not an individual pursuit, but a collective one. They were all of us. The air was thick with ghosts - every life lived on that land, every life lived in that story" (Ausubel 292). It is the ghosts and the wasted lives that Holocaust discourses, whether fictional or not, expose. Irving Howe in The Journey of the East European Jews to America and the Life They Found and Made speaks of "an outpouring of rhetoric" in the aftermath of the Holocaust: "Jewish scholars patiently accumulated historical data concerning the Holocaust, driven by a kind of clenched meticulousness to scrape together every last, unbearable fact. And there was a quantity of literary effort, most of it doomed to a failure of mere language" (626). While the failure of language is natural in the immediate proximity of the trauma-causing events, Ausubel, generations removed from her predecessor's direct experiences, attempts to find new, inventive ways of mourning, coping with and working through the trauma.

\section{CONCLUSION. THE PRIVILEGE OF REMEMBERING}

Under a motto that appears late in the novel as a revelation, "it is a privilege to remember" (Ausubel 290), the author converts her grandmother's tales into an empathic attempt to "understand what it might have felt like, rather than to catalogue precisely what happened [...]". In her interview for The Paris Review, she confesses her initial intimidation by the thought of writing about a time and place she was not directly familiar with: "The way I chose to think about it was that, inevitably, each of us fails to communicate a thing so huge, so terrible, but perhaps all our voices together begin to describe the truth. I am just adding one more small voice” (qtd. in Hunt). Thus, the collective story she designates Lena 
to carry to a different continent and world altogether is a collection of individual versions of a collective tragedy. By this the author contributes a new perspective to the reflection of memory and authenticity in the emotionally impactful truths of fiction.

Lena's plight belongs to an entire community, and her voice is the embodiment of resistance to the burden of shared trauma. The scene that unfolds in the living room of her temporary host family, after her arrival to America, is most relevant for the commonality of a painful history and the impossibility to fully articulate it, which lie at the heart of Ausubel's impressive debut novel.

They did not sit me up, ask me my name or rush me to the doctor. Maybe because they saw the way my sadness had spilled out over the edges of my cupped palms, maybe because they knew the stories that kept arriving with each new shipment of people from the old world, maybe because they remembered all the ways they too were tired - whatever the reason, the man and the woman wordlessly lay down on either side of me. We stared at the cracked ceiling, we ignored the three children asking what was wrong with us, and we wept. (Ausubel 389)

\section{Works Cited}

Ausubel, Ramona. No One Is Here Except All of Us. New York: Riverhead Books: New York, 2012. Print.

Bernard-Donals, Michael; Glejzer, Richard (eds.). Witnessing the Disaster. Essays on Representation and the Holocaust.Madison, Wisconsin: The University of Wisconsin Press, 2003. Print.

Caruth, Cathy. Unclaimed Experience. Trauma, Narrative, and History. Baltimore and London: The Johns Hopkins University Press, 1996. Print.

Dawidowicz, Lucy S. A Holocaust Reader. Springfield. N.J.: Behrman House, Inc. Publishers (Library of Jewish Studies), 1976. Print.

Hendrix, Jenny. "Lost and Saved". Los Angeles Review of Books. 27 Feb. 2012. https://lareviewofbooks.org/article/lost-and-saved/. Web 30 March 2016.

Howe, Irving. World of Our Fathers. The Journey of East European Jews to America and the Life They Found and Made. Washington Square, New York: New York University Press. 2005. Print.

Hunt, Samantha. “Adaptation: An Interview with Ramona Ausubel.” The Paris Review. 7 June 2012. https://www.theparisreview.org/blog/2012/06/07/adaptation-aninterview-with-ramona-ausubel/. Web. 20 April 2015.

Rothberg, Michael. Traumatic Realism. The Demands of Holocaust Representation. Minneapolis, London: University of Minnesota Press, 2000. Print. 